\title{
防波堤に书忛方越水機構と氷盤の移動速度に関する矿究 \\ Overtopping Velocity of Ice Floe on the Breakwater due to Tave Action
}

酒井裕二* 高橋良正 三谷朋行** 山下俊彦***佐伯 浩***

Yuji Sakai, Yosimasa Takahasi, Tomoyuki Mitani, Toshihiko Yamashita, Hiroshi Saeki

\begin{abstract}
The Okhotsk Sea coast of Hokkaido is covered with drift ice in winter. When ice floe concentration is low, sometimes overtopping of ice floe occur at breakwater due to wave action. Fishing boats and pipelines behind breakwater hava been dameged by the ice floes. It is required that ice control facilities are constructed. In order to design the facilities, we have to know the overtopping velocity of ice floe on breakwater.

We report on the systematic experimental results on overtopping of ice floes and its mechanisms.
\end{abstract}

Keywords: overtopping, verocity of ice floe, breakwater

1.はじめに

北海道ではオホーツク海沿岸域を中心に日本海侧や太平洋侧の一部でも冬期に流水の来竐がみられる。沿岸部 での流水の密接度が高く、広簕团に海面が被罗されているときには流水による波浪の減衰効果がみられるが、密 接度が低いときは流水による波浪の減瑟効果が小さく高波浪が生じやすい。高波浪時に防波堤上を水盤が越える 事もしばしば見られる。最近では防波堤の背後が岸壁として利用され、また、それに䇟接してドルフィンやパイ プラインが作られたりしているが、実際に網走港では越水により南防波堤背後のパイプラインやドルフィン、上 架中の魚船への被害も報告されている（秋原ら1992）。一方、棓水防波堤では人々が流水を見る為に防波堤上を 散策することになるが、越水により防波堤天端上に水整が堆積することは交通や散策の障害となり本来の親水の 目的に反し望ましいとは言えない。

越水を制御する方法としては防波堤の天端高さを上げることが考えられるが、防波堤断面の增加によるコスト 增や、防波堤を支持する地盤の強度の面などからも必ずしも有効な手段とは言えない。親水防波堤はともかくと して、ドルフィンやパイプラインでは多少の越波では機能を損なうことはないので、防波堤の天端高さを嵩あげ するよりも防波堤の天端上に越水を防止する柵のような構造物を設ける方が有効となる。このような構造物を設 計する際にどのくらいの水力がかかるのかを知る必要がある。氷篮の運動による構造物に作用する衝慗力を決め る因子としては、水盤の大きさ、強度、移動速度、構造物の形状と有効幅などが考えられる。ここで、Kreider (1984)の衝撃水力は(1)式で示される。(1)式は運動量の関係から得られたものである。

$$
\begin{gathered}
\mathrm{F} \mathrm{m}=2.66 \mathrm{~h} \\
\mathrm{~F}_{\mathrm{m}}: \text { : 水力 }\left(\rho_{\mathrm{i}} \mathrm{Dgf}\right)^{1 / 3}\left(\sigma_{\mathrm{c}} \mathrm{R}_{\mathrm{i}} \mathrm{V}_{\mathrm{i}}\right)^{2 / \mathrm{s}} \\
\mathrm{h}: \text { 水盤の厚さ }(\mathrm{cm}) \\
\rho_{\mathrm{i}}: \text { 水盤の密度 }\left(\mathrm{kg} / \mathrm{cm}^{3}\right) \\
\mathrm{D}: \text { 構造物の半径 }(\mathrm{cm}) \\
\sigma_{\mathrm{c}}: \text { 水の平均压縮強度 }\left(\mathrm{kgf} / \mathrm{cm}^{2}\right) \\
\mathrm{R}_{\mathrm{i}}: \text { 水盤の半径 }(\mathrm{cm}) \\
\mathrm{V}_{\mathrm{i}}: \text { 水盤の移動速度 }(\mathrm{cm} / \mathrm{sec})
\end{gathered}
$$

また、佐伯らによる氷盤の貫入速度により得られた実験式は(2)式で示される。

$$
\mathrm{F} \mathrm{m}=5.0 \quad \mathrm{~K} \quad \sqrt{\mathrm{D}} \mathrm{h} \quad \sigma_{\mathrm{c}} \quad \cdots(2)
$$

$\mathrm{D}:$ 円形断面の構造物の直径 $(\mathrm{cm})$

$$
\mathrm{K} \text { : 水盤の貫入速度によって決定される俰数（高速の場合 } \mathrm{K}=0.8 ）
$$

$\begin{array}{llll}* & \text { 学生員 } & \text { 北海道大学大学院 } & (060 \text { 札幌市北区北13条西8 } 8 \text { 目 }) \\ * * \text { 正員 } & \text { 東亜建設工業 } & & \\ * * * \text { 正員 } & \text { 北海道大学工学部 }\end{array}$


以上のような2つの式より計算された結果で小さい方の 值を採用すれば良いことになる。(1)式において氷の運動 から水力を求めるときには水盤の移動速度が必要亡なる が、水盤の大きさや強度については國松らの研究があり、 波浪による水盤の運動については泉山らの実験結果が報 告されているが、水盤の越水時の移動速度についての研 究はなされていない。そこで、本研究ではこのような越 水制御の構造物を設計する場合の構造物部材に作用する 衝撃水力を求めるために必要な水盤越水時の水盤の移動 速度の特性を明らかにすることを目的としている。

\section{2.実験装置及び実験条件}

実験に用いた水路は幅 $80 \mathrm{~cm}$ 、長さ $24 \mathrm{~m}$ の銅製の造波水 路で、水盤の挙動が見えるように両面ガラス張りのもの である。また、砕波による影整をより顥著にするために 実際の海底勾配より屯急勾配とし、水路の勾配は $1 / 30$ と した。その概略を図-1に示す。防波堤の模型は図-2に示 したような直立堤であり天端高さは 2 種類である。そし て、オホーツク海沿岸の網走港や紋别港での実際の防波 堤の設置水深は約 $10 \mathrm{~m}$ であり、本実験でも同様な水深で、 縮尺 $1 / 50$ で $20 \mathrm{~cm}$ とした。水盤の模型としては比重が約 0.8 5 と海水とほほ等しいパラフィン盤を使用した。また、今 回の実験においては流体と模型水盤との摩擦係数が問題 となるが、このことは上田ら(1992)の研究により、実水 盤の模型としてパラフィン盤が適当であることが明らか にされている。また、パラフィン盤の大きさについては 宇登呂漁港南側海岸での調查結果（國松ら(1993)) より 実際の水盤の大きさは 1 辺 $2 \mathrm{~m} \sim 4 \mathrm{~m}$ の正方形に相当する 面積のものが最も多いという結果を参考にして表一1のよ うな条件で実験を行った。また、対象となるオホーツク 海沿岸の港㴒における構造物の設計波は、波高 $10 \mathrm{~m}$ 、周 期は12.3秒であり、このことを考虑し、フルードの相似 則により周期は $1.70 、 1.41 、 1.13$ 秒（実際の周期では $12 、$ $10 、 8$ 秒）の3種類、波高は18、15、12、9cm（実際の波高で は9、7.5、6、4.5m) の4種類である。次に実験方法であ るが、各条件で造波後に防波堤前面約 $70 \mathrm{~cm}$ の位置で水盤 を1枚ずつ投入しその挙動を観察した。また、1/30秒まで 解析可能なビテオカメラを用いて予め水路のガラスに刻 んであるメッシュにより防波堤天端前面での水盤の移動 速度、越水高さを求めた。移動速度の算定には防波堤前 面の前後 $5 \mathrm{~cm}$ での水盤の重心位置の移動時間とその角度

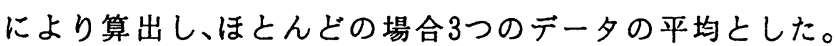
図-3に越水高さと移動速度の定義を示す。

表一 1 パラフィン盤の寸法

\begin{tabular}{c|c}
\hline パラフィン盤の寸法 & 実際の寸法 \\
\hline $16 \mathrm{~cm} \times 16 \mathrm{~cm}$ & $8 \mathrm{~m} \times 8 \mathrm{~m}$ \\
\hline $12 \mathrm{~cm} \times 12 \mathrm{~cm}$ & $6 \mathrm{~m} \times 6 \mathrm{~m}$ \\
\hline $8 \mathrm{~cm} \times 8 \mathrm{~cm}$ & $4 \mathrm{~m} \times 4 \mathrm{~m}$ \\
\hline $4 \mathrm{~cm} \times 4 \mathrm{~cm}$ & $2 \mathrm{~m} \times 2 \mathrm{~m}$ \\
\hline
\end{tabular}
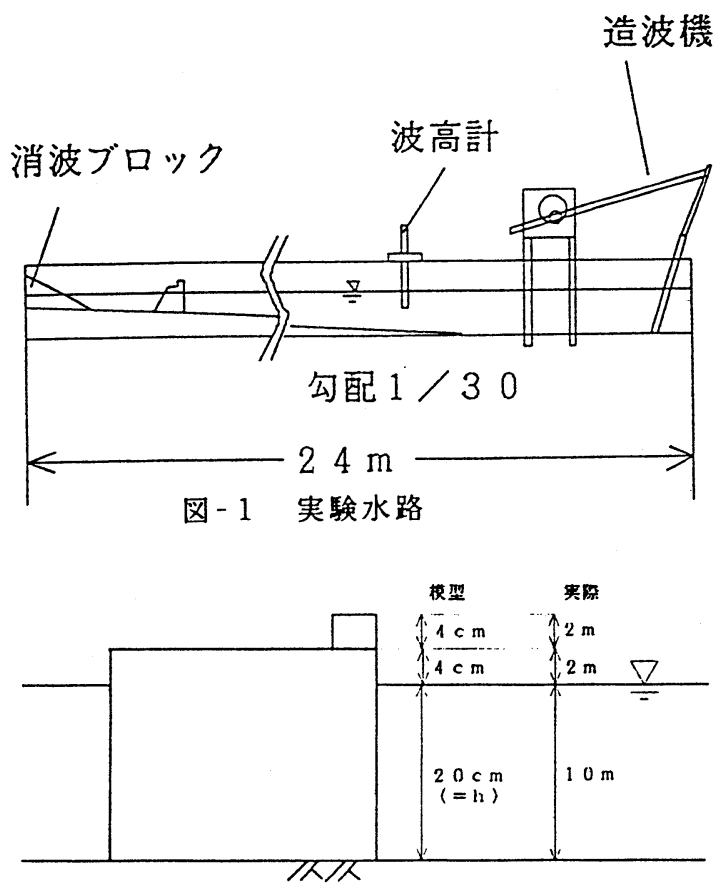

図-2防波堤断面

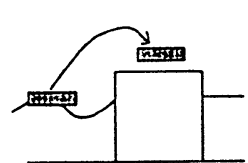

( a )

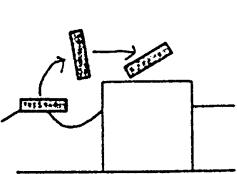

(b)

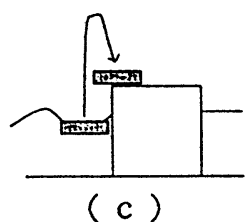

図-3 水盤の越水形態

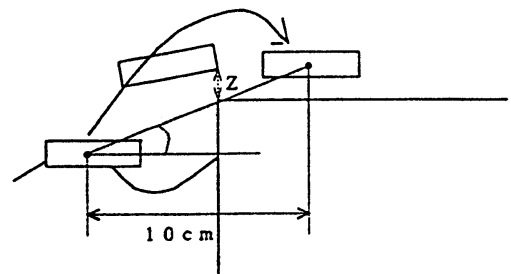

図-4 越水高さと移動速度の定義

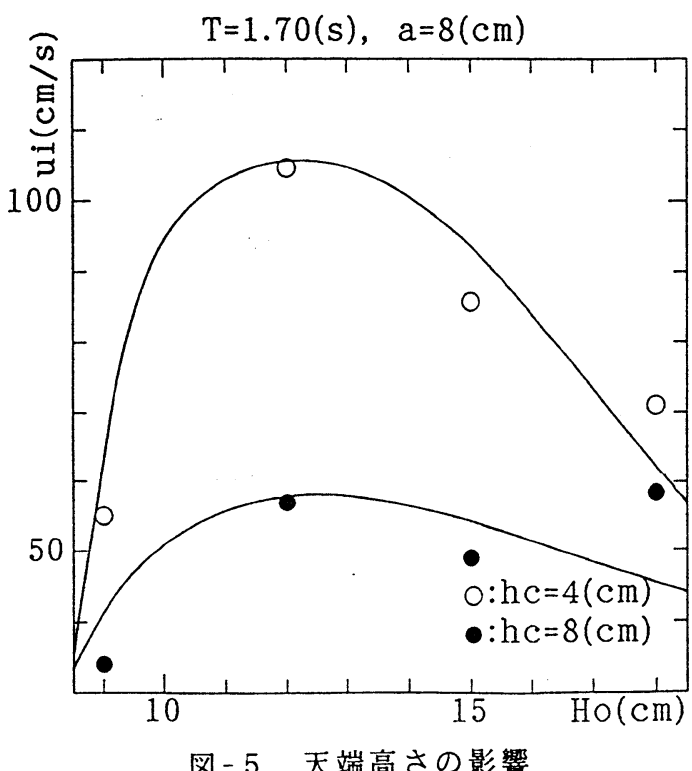

図-5 天端高さの影響 


\section{3.実験結果とその考察}

表一1に示したような4種類の大きさの水盤でそれぞれ $1 、 2 、 3 、 4 \mathrm{~cm}$ (実際の厚さ50、100、150、200cm)の厚さで実 験を行ったが厚さの越水量への影淛は見られたが、越水 速度には有意な差はみられなかった。そのため、以下に おいては越水速度の值は全て厚さによる平均值としてあ る。

越水の形態としては 図-4に示すように大きく3つの夕 イプに分類される。まず、平行に越えていくタイプ(a)と 波の進行方向に回転していくタイプ（b)と天端上には越 水するもののほとんどが鉊直方向にしか移動せず水平方 向の移動かこく僅かなタイプ(c)が観察された。この3つ の越水形態は波浪条件や構造物の天端高さ等とほとんと 無関係であった。また、条件によっては全く越水をしな いケースも見られたか、、本研究では越水の可能性の条件 を明らかにすることよりも、越水速度に注目しているの で以下越水しなっかたケースや水平方向の速度が小さく、 その結果として氷力が小さいと予想されるもの（Cタイ プ）については無視した。

同一諸元の水盤で、かつ同粎な越え方をしたにもかか わらす、越水速度にはかなりのばらつきが見られた。今 回はおおよその傾向を知るためにも平均値で表すことに した。

まず、図一5に水盤の移動速度 $\left(\mathrm{u}_{\mathrm{i}}\right)$ と沖波波高 $\left(\mathrm{H}_{0}\right)$ の関係を天端高さ $\left(\mathrm{h} \mathrm{c}_{\mathrm{c}}\right.$ )ことに表した一例を示す。他の 条件のケースですほほ同じ傾向である。天端高さが高く なるほど氷盤移動速度 u i が遅くなる傾向がわかる。この ことは天端高さが高くなるにしたがって越波量は隇少し、 より重複波的になることを考えれば当然のことである。

図-6に氷盤の移動速度と波高の関係を表した一例を示 す。周期1.13秒の場合には波高が增すにつれて氷盤の移 動速度が大きなっている。しかし、周期が1.70秒や1. 41秒の場合にはそのような有意な傾向はみられない。

図一7には氷盤の移動速度と周期の関係の一例を示した。 防波堤堤体がなく進行波で砕波地点を考えた場合、防波 堤設置位置より沖側で砕波しているもの（ $\mathrm{H}_{0}=18,15$ (c m)）には周期之水盤の移動速度での有意な傾向はみられ ないが、防波堤設置位置より陸側で砕波しているもの $\left(\mathrm{H}_{0}=12(\mathrm{~cm})\right) \quad$ は周期が長くなると氷盤の移動速度が 速くなる傾向がみられる。この理由としては砕波後に波 高が減衰しているため、防波堤前面での波高が沖での波 高よりも小さくなっているためだと考えられる。また、 $\mathrm{H}_{0}=9(\mathrm{~cm})$ の場合は防波堤設置位置より陸側で砕波して いるが、水盤が越水するかしないかの限界であり、その ためにテータのばらつきが激しく系統的な傾向はみられ ない。

図-8は各 $\mathrm{h} / \mathrm{L}$ 。( h : 防波堤設置水深、L。：沖波波 長) での $\mathrm{H}_{0} / \mathrm{h}_{\mathrm{c}}\left(\mathrm{h}_{\mathrm{c}}\right.$ : 天端高さ)による $\mathrm{u}_{\mathrm{i}} / \mathrm{u}(\mathrm{u}$ : 進行波の水粒子水平移動速度の最大值) $<\mathrm{a} / \mathrm{L}$ 。( $\mathrm{a}$ : 水盤の1辺の長さ）との関係を示したものである。

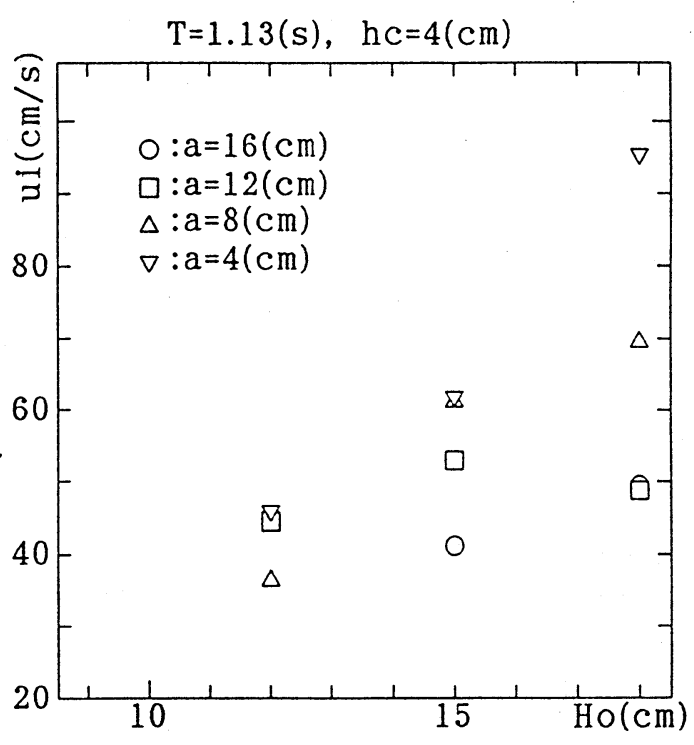

図－6-（a）水盤移動速度と波高の関係

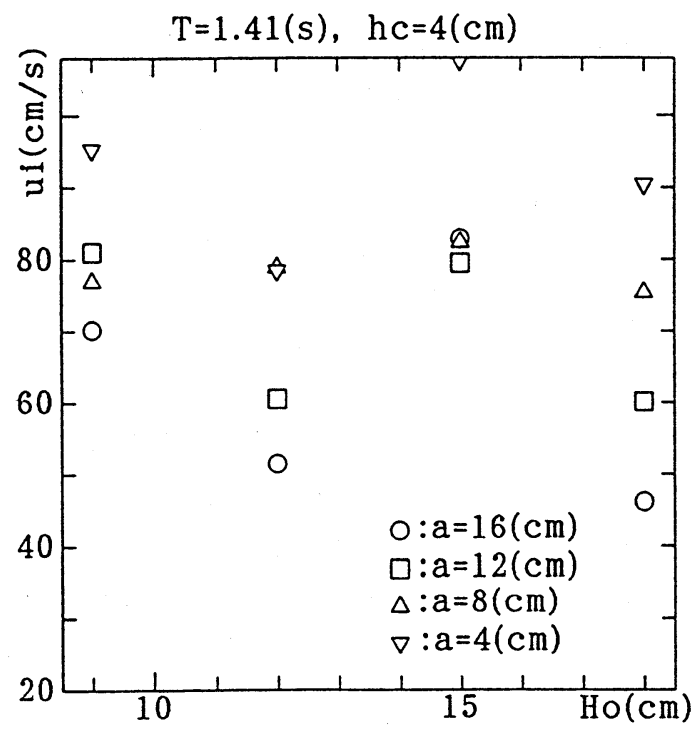

図-6-(b) 水盤移動速度亡波高の関係

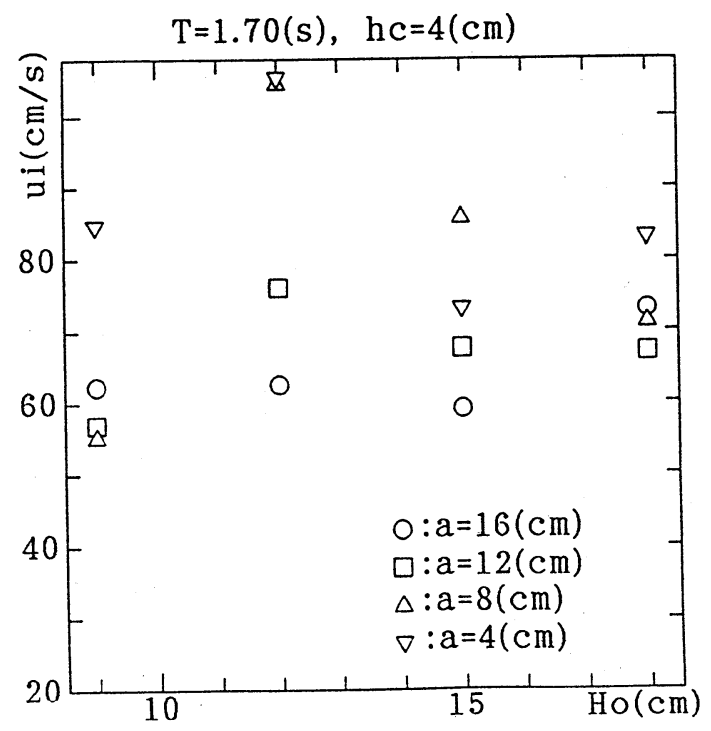

図-6-(c) 水盤移動速度と波高の関係 
ここで、水粒子の移動速度 uは

$u=\frac{\pi \mathrm{H} \cosh 2 \pi(h+z) / L}{\mathrm{~T} \sinh 2 \pi h / L}$ i n $\left(\frac{2 \pi}{\mathrm{L}} \mathrm{x}-\frac{2 \pi}{\mathrm{T}} \mathrm{t}\right)$ -..-(3)

の $\mathrm{z}=0$ (静水面) での最大值を基準として用いた。 本来なら部分重複波であるが、越波をしているため進行 波の傾向もあるのでuは進行波の水粒子移動速度を便宜 的に用いている。 $a / L$ 。が大きくなるにつれて $u_{i} / u$ が小さくなるという一般的な傾向がわかる。つまり、線 形波動の水盤の移動速度は a / L。に依存している。また、 かなりのケースでui / u が1より大きく、最大では $2.8 と$ なっている。つまり、進行波の水粒子移動速度の最大值 より水盤の移動速度が速くなっていると言うことである。 これは勾配が $1 / 30$ と急勾配でかつ波形勾配が大きいため に起こる波の非対称性が理由であり、そのために波動理 論が直接使えないが解析での便宜を考えて微小振幅波と して扱っている為の影胳であると考えられる。

次に越水する水盤の防波堤上の通逦する位渻 $z$ につい て調へた。これは越水防止施設を設計する際の行慗水力 の作用位置を知るためである。

図-9に $\left(\mathrm{H}_{0}-\mathrm{h}_{\mathrm{c}}\right) / \mathrm{z}$ と $\mathrm{a} / \mathrm{L} 。$ の関係の一例を示 す。( $\left.\mathrm{H}_{0}-\mathrm{h}_{\mathrm{c}}\right) / \mathrm{z}$ は a / L 。に依らずほほ一定の值を 取った。これは他の条件でも同様の結果であった。つま り、越水高さ $z$ は $\mathrm{a} / \mathrm{L}$ 。に依存していないことが明かと なった。

図-10に $\left(\mathrm{H}_{0}-\mathrm{h}_{\mathrm{c}}\right) / \mathrm{z}$ と $\mathrm{H}_{0} / \mathrm{L}_{0}$ の関係の一例を 示す。越水高さ $z$ は $\mathrm{h} c / \mathrm{h}$ の影整を受けた。実線は $z$ か 最大側、点線は最小側の包絡線を示した。これは水力の 作用位置の最大の範囲を示したものである。越水高さ $\mathrm{Z}$ については波浪条件や構造物の条件との関係を調へたが 良い相関は得られなかった。実際に越水制御構造物を設 計する場合には最も安全側の実線の值を用いて越水高さ を決めれば良いと思われる。

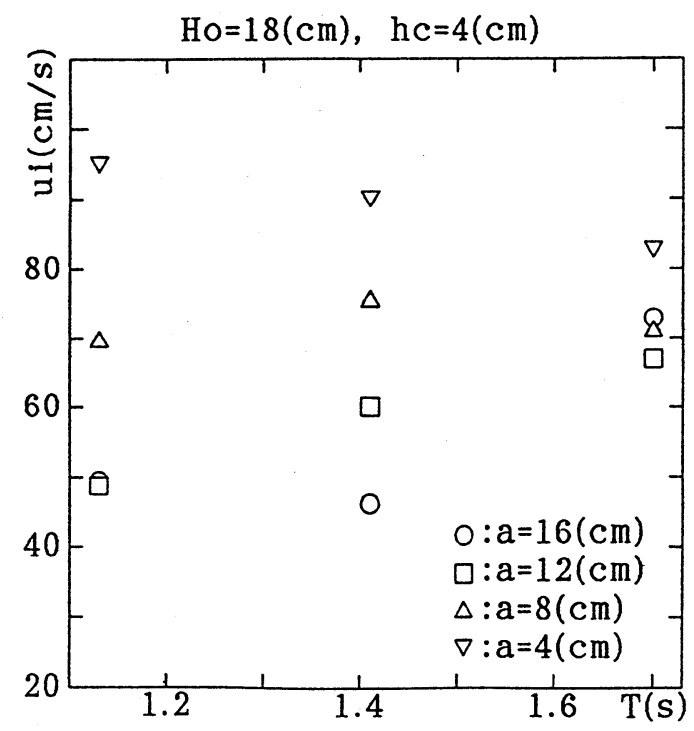

図-7-（a）水瞥移動速度と周期の関係

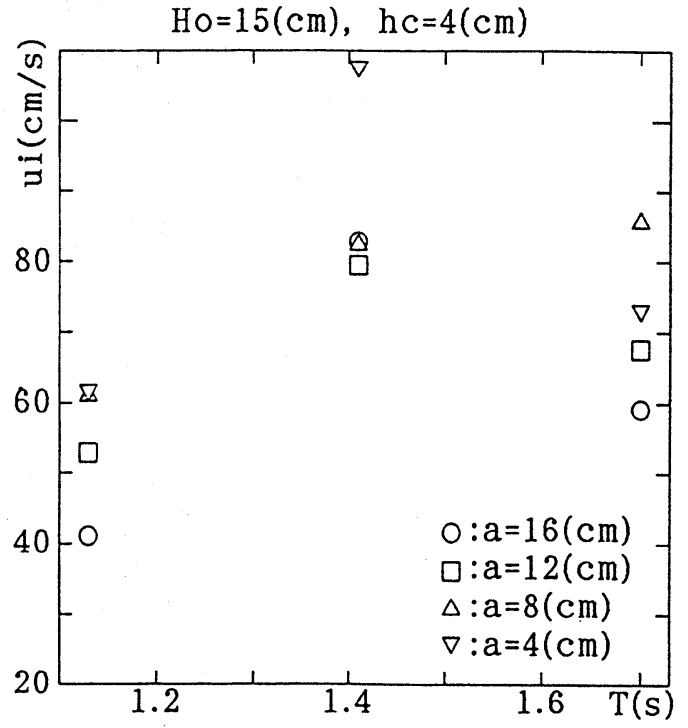

図-7-(b) 水盤移動速度と周期の閶係

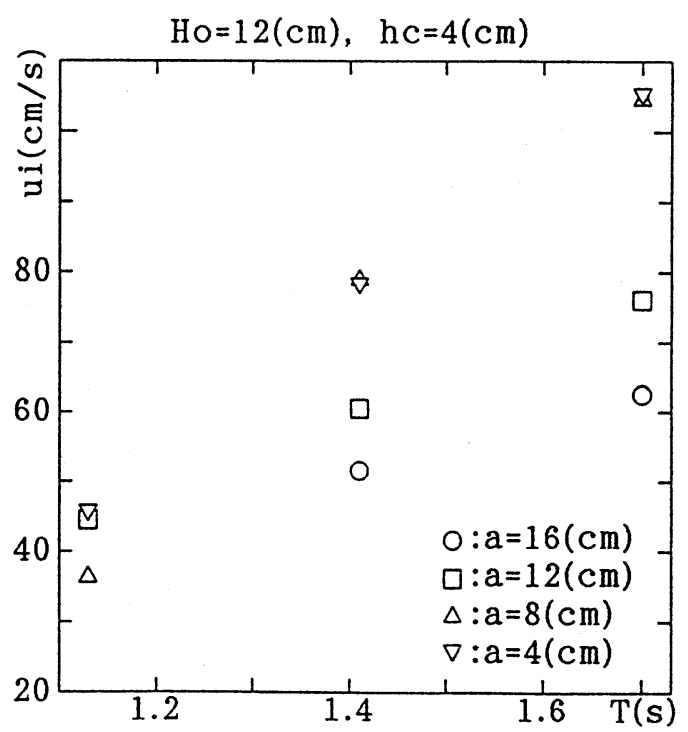

図－7-（c）水盤移動速度と周期の関係

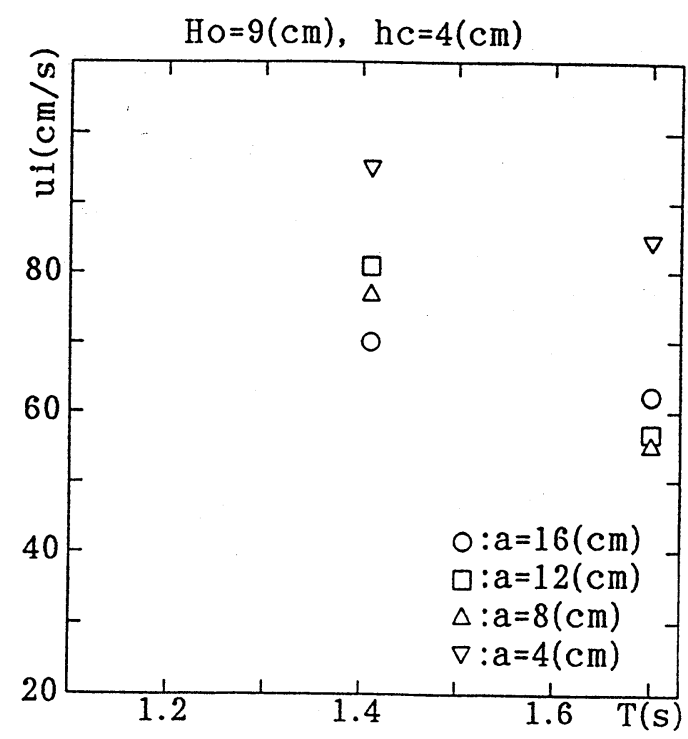

図 - 7 -(d) 水盤移動速度と周期の関係 


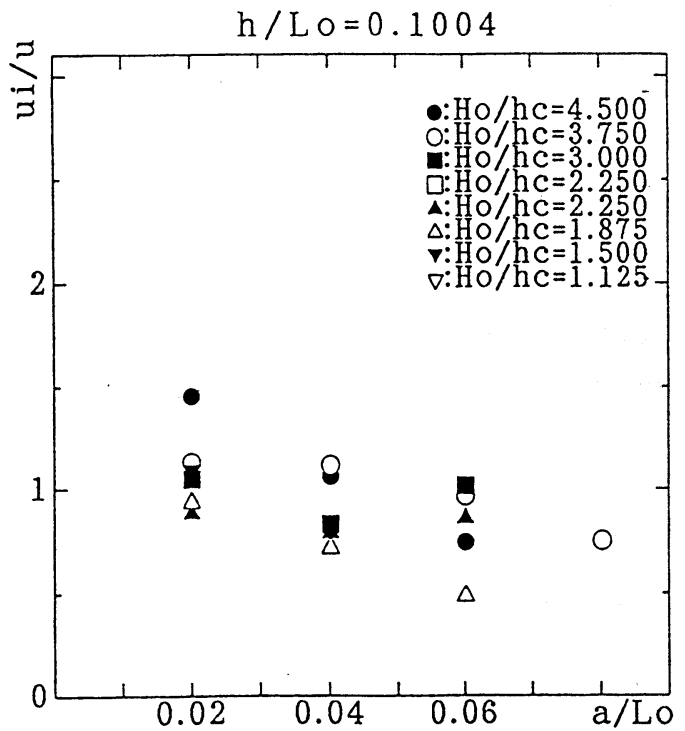

図-8-(a) ui/ u亡a/L。の関係

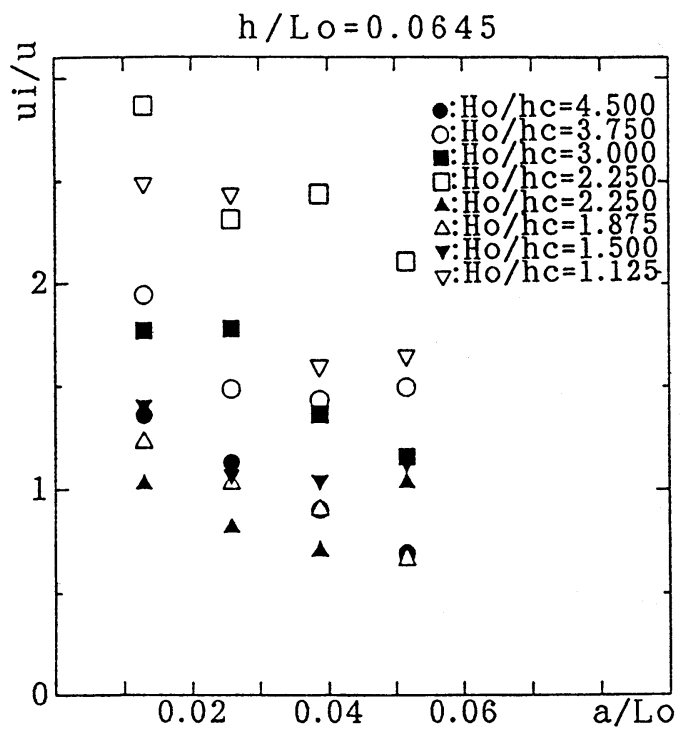

図-8-(b) u i / u と a / L。の関係

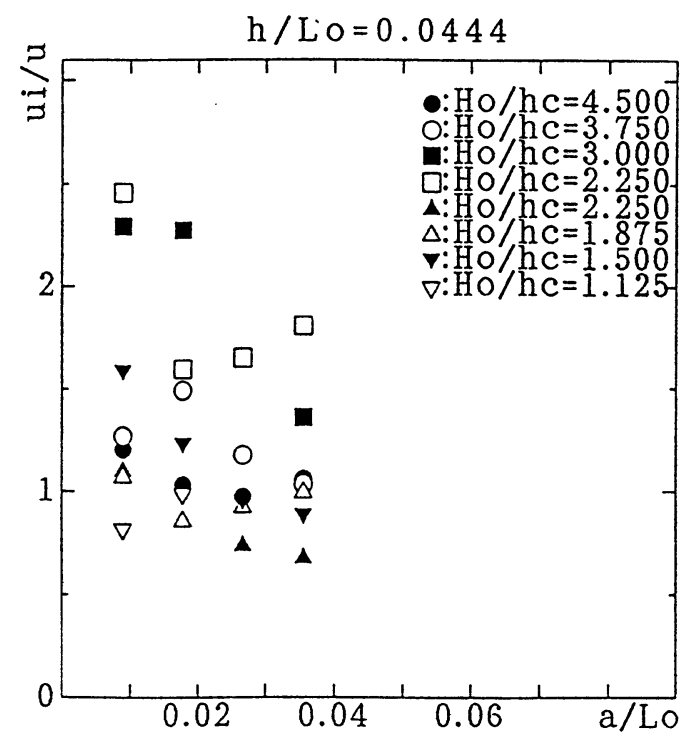

図-8-(c) $u_{i} / u_{\text {と }} \mathrm{a} / \mathrm{L}$ 。の関係

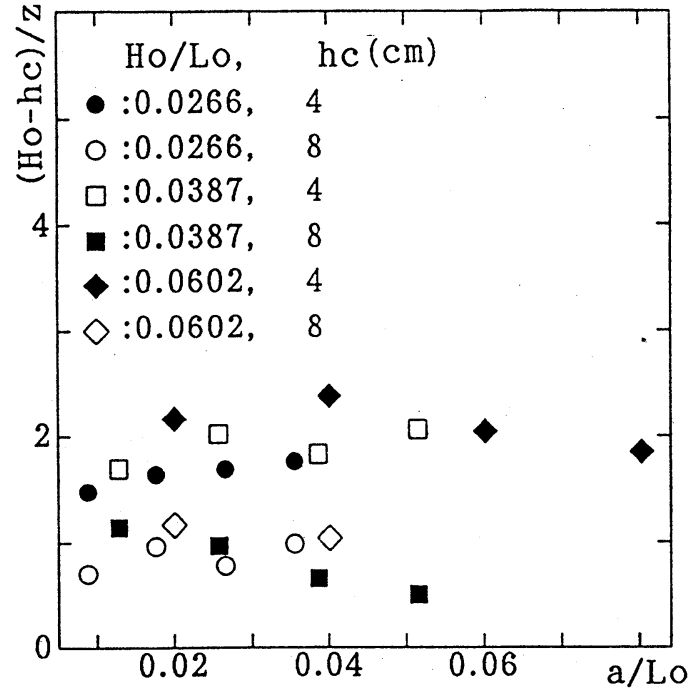

図-9 $\left(\mathrm{H}_{0}-\mathrm{h}_{\mathrm{c}}\right) / \mathrm{z}$ と $\mathrm{a} / \mathrm{L}$ 。の関係

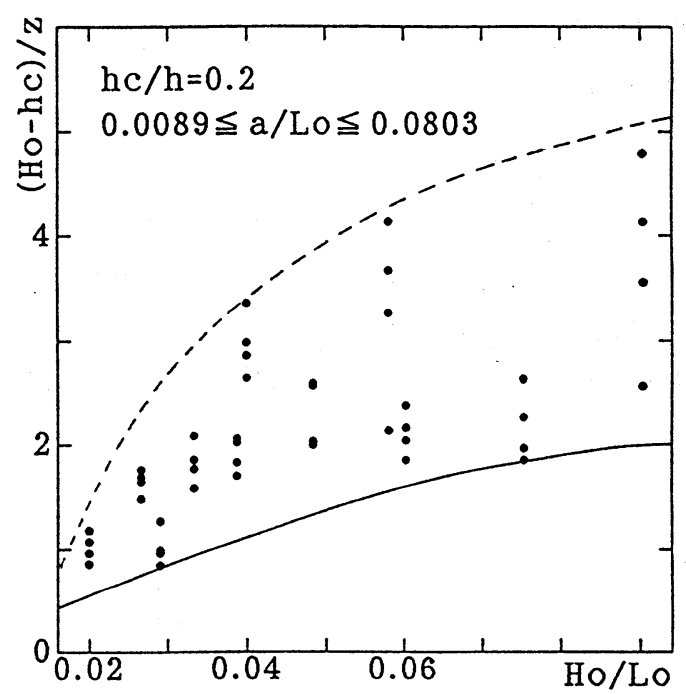

図-10-(a) $\left(\mathrm{H}_{0}-\mathrm{h}_{\mathrm{c}}\right) / \mathrm{z}$ と $\mathrm{H}_{0} / \mathrm{L}_{0}$ の関係

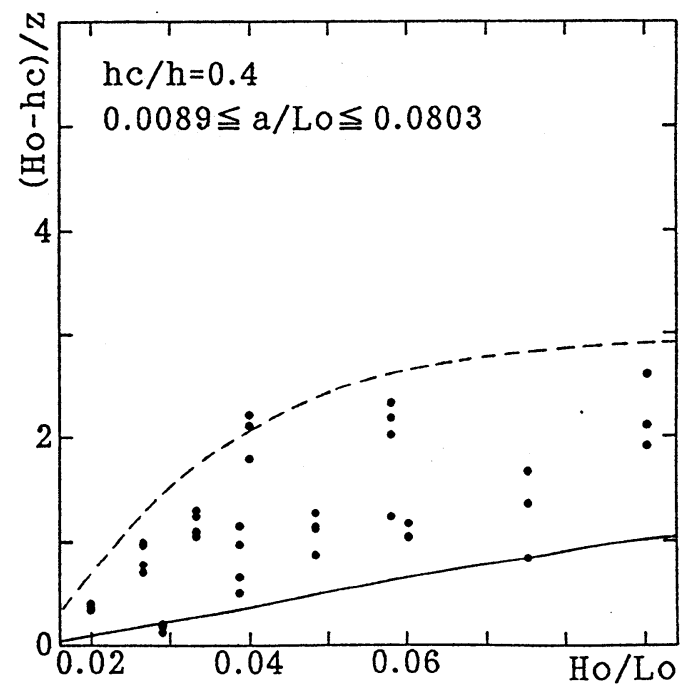

凶- $10-(b)\left(H_{0}-h_{c}\right) / z<H_{0} / L_{0}$ の関係 


\section{4.まとめ}

本研究で得られた主な結論を以下にまとめると、

(1)越水の形態は 3 種類に分類された。

(2)水盤の厚さによる有意な差は厚さ $1 \mathrm{~cm} 〜 4 \mathrm{~cm}$ （実寸 $50 \mathrm{~cm} ２ 00 \mathrm{~cm}$ ）の範囲ではみられなかった。

(3)天端高さが高くなると水盤の移動速度は遅くなった。

(4)越水時の水盤の移動速度は $\mathrm{a} / \mathrm{L}$ 。が增加すると遅くなり、 $\mathrm{a} / \mathrm{L}$ 。に依存した。

(5)防波堤設置位置より沖侧で砕波しているものには周期と水整の移動速度での有意な傾向はみられないが、防波 堤設置位置より陸側で碎波しているものは 周期が長くなると水瞥の移動速度が速くなる傾向がみられた。また、 $\mathrm{H} 。=9(\mathrm{~cm})$ の場合は水蟞が越水するかしないかの限界であり、そのためにデータのばらつきが激しく系統的な傾 向はみられなかった。

(6)越水時の氷盤の移動速度は周期が1.13秒の場合には波高が增すにつれて氷盤の移動速度が大きくなっているが、 周期が1.70秒や1.41秒の場合にはそのような有意な傾向はみられなかった。

(7)越水高さは $\mathrm{a} / \mathrm{L}$ 。に依存せず、 $\mathrm{h} \mathrm{c} / \mathrm{h}$ の影響を受けた。

(8)移動速度は図-8により、作用位監は図-10により決まり、よって氷力とそのモーメントが求められる。

\section{参考文献}

1)國松、原、高橋、佐伯、极、今泉：オホーツク海沿岸部の流永篮の大きさに䍘する研究、海洋開発シンポジゥ 厶1993, pp95-100

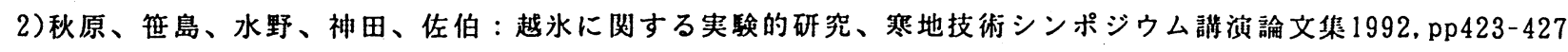

3)Kreider : Summer Ice Impact Loads from Hultiyear Floes、Proc. IAHR Ice Sympo. Vol.2, Hamburg, pp55-66

4)泉山、佐伯、尾崎: 波浪による水盤の遇動に関する研究、土木学会北海道支部論文報告集1981, pp 135-140

5)上田、佐伯、山下、村木、极：浮水整に作用する流体力に関する実験的研究、海洋開発シンポジゥム1992, pp 1 $35-140$

6)中澤、竹内、小野、佐伯：海洋構造物に作用する氷力式の評価、海洋開発シンポジゥム 1986, pp 115-120 